\title{
節付き場所打ち杭の節部抵抗力の実用的な評価方法 EVALUATION METHOD ON RESISTANCE OF NODULAR PART FOR NODULAR CAST-IN-PLACE CONCRETE PILE
}

\author{
須藤 敏 巳*, 土屋 勉 ${ }^{* *}$, 渡邊康 司 ${ }^{* * *}$
}

\section{Toshimi SUDO, Tsutomu TSUCHIYA and Koji WATANABE}

\begin{abstract}
This paper describes the evaluation method on the resistance of a nodular part for nodular cast-in-place concrete pile acting both compressive and tensile loads in sandy ground. The resistance of a nodular part is properly separated into three components, the shear resistance of cylindrical area, $R_{\mathrm{s}}$, the bearing pressure of circular area, $R_{t b}$, and the shear resistance of inclined area due to the increase of horizontal stress, $R_{t s}$. The validity of the evaluation method were examined by comparing the calculated values and the results of in-situ vertical loading tests.
\end{abstract}

Keywords : nodular cast-in-place concrete pile, evaluation method, coefficient of earth pressure, inclined angle of nodular part, in-situ vertical loading test 節付き場所打ち杭，節部抵抗力の評価方法，水平土圧係数，節部傾斜角度，原位置載荷試験

1. 序

近年，アスペクト比の大きな高層の集合住宅やオフィスビルの建 設が増加している．このような高層建築物を支持する杭体には地震 時や暴風時に大きな押込み力と引抜き力が作用するため, 最近では 図 1 や写真 1 のように杭の中間軸部に節部を設けた節付き場所打ち 杭（以下，節付き杭）が採用される事例も報告されている.

節部抵抗力の評価法は, 図 2 に示寸せん断法 $\left.{ }^{1)}, 3\right)$ や図 3 に示寸支 圧法 ${ }^{11}$, 2) が提案されている. 前者は節部径に外接する円筒面に作用 する地盤のせん断力で評価し, 後者は節部径と軸部径の間の円環状 の鉛直投影面に作用寸る支圧力で評価する方法である。これらの評 価法は載荷試験で得られた節部抵抗力と地盤の一軸圧縮強さ $q_{u}$ や $N$ 值の相関性から導かれた経験式である。

一方，理論式による節部に関する既往の支持力評価法としては, 八尾ら ${ }^{4)}$, 小椋ら ${ }^{5)}$, 本田 ${ }^{6)}$ による研究があり, 節部傾斜面によ る支持力増大は節部の突出幅と傾斜角度, 杭表面の壁面摩擦角の大 きさに依存すると考えられる，このような傾斜面による支持力増大 の考え方は古くから論じられており，1/100 程度のテーパー角を有 する木杭がストレート杭の 2 倍程度の周面摩擦抵抗を発揮する報告

7)もある。

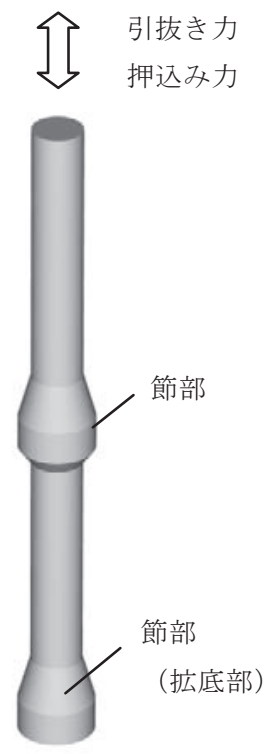

図 1 節付き杭

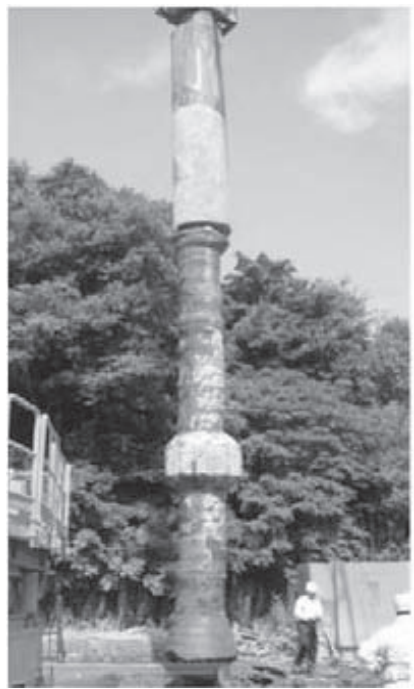

写真 1 節付き杭

（掘出した試験杭）
$*$ 室蘭工業大学大学院工学研究科建設環境工学専攻 大学院生 (侏)大林組特殊工法部

** 室蘭工業大学大学院工学研究科 教授. 工博

*** (侏大林組技術研究所地盤技術研究部 研究員 · 修士 (工学
Graduate Student, Div. of Architecture, Civil and Environmental Engineering, Graduate School of Engineering, Muroran Institute of Technology

Specialty and Engineering Department, Obayashi Corporation

Prof., Graduate School of Engineering, Muroran Institute of Technology, Dr. Eng.

Researcher, Geotechnical Engineering Department, Technical Research Institute, Obayashi Corporation, M. Eng. 


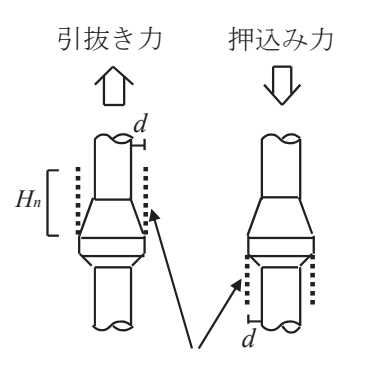

円筒せん断面の仮定高さ： $H_{n}$

図 2 せん断法 1 1), 3)

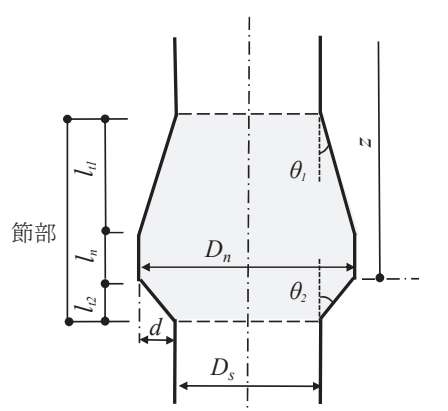

図 4 節付き杭の各部名称

本論文は，節部傾斜面に接続する環状の土塊に作用する力のつり 合いに基づいて, 砂質土地盤における単一の節部を有する杭の節部 抵抗力の実用的な評価法を検討したものであって, 以下のような特 徵を有している。

(1). 杭が施工された時点の水平方向地盤応力（杭頭部載荷直前であ つて初期応力）を評価するために, 通常の円形の場所打ちコンク リート杭の載荷試験結果を収集整理して, 深さ方向の水平土圧係 数（以下，土圧係数） $K$ の分布算定式を誘導している.

(2). 節部外周面においては, (1)で誘導した $K$ と周面地盤の境界面で のせん断抵抗角 $\delta$ を仮定した上で, 地盤の水平方向初期応力に基 ら゙いて支持力を評価している.

(3). 節部傾斜面においては, 傾斜面に接続する三角形の環状の土塊 （本論文では, 環状楔と呼ぶ）を仮定して, 環状楔の底面に生じ る鉛直力による支持力と側面に生じる水平力による支持力を評価 している.

(4). (2)〜 (3)による節部の抵抗力評価式を構築した後, 実大規模の節 付き杭の載荷試験結果と比較することによって, その妥当性を検 証している。

なお，本論文では節付き杭の各部名称を図 4 に示すように定義し ており，節部とは上部傾斜面の上端から下部傾斜面の下端までの範 囲である.

\section{2. 節部抵抗力の基本的考え方}

節部抵抗力（特に断りがない限り，極限抵抗力を意味している） に関する本論文の基本的考え方を示す．図 5 は押込夕荷重が作用す る場合を例示したものであるが，節上端の軸力 $N_{o}$ と節下端の軸力 $N_{u}$ の差が節部の全抵抗力 $R_{n}$ となる．ここで，節上部の傾斜面（ $l_{t l}$ の範囲）は杭周面の地盤から離間する方向に変位するので，この部

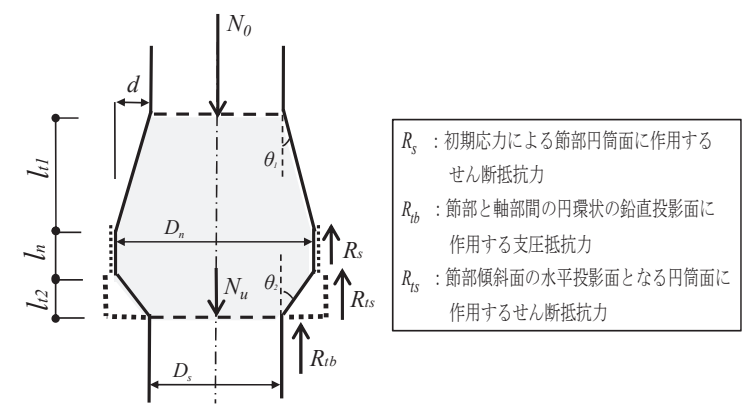

図 5 節部の支持力成分（押込み力を受ける場合）
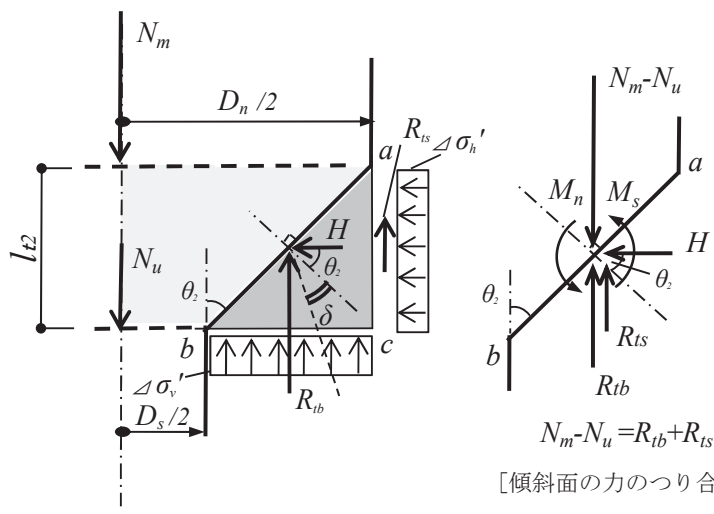

$N_{m}-N_{u}=R_{t b}+R_{t s}$

[傾斜面の力のつり合い]

図 6 節部傾斜面の支持力（押込み力を受ける場合）

分の抵抗を無視すると, 節部の全抵抗力 $R_{n}$ は以下に示す 3 成分 $\left(R_{s}\right.$, $\left.R_{t b}, R_{t s}\right)$ の累加式で表されると仮定できる.

$$
R_{n}=R_{s}+R_{t b}+R_{t s}
$$

\section{a . 節部円筒面のせん断抵抗力 : $R_{S}$}

$R_{s}$ は節部周面 $\left(l_{n}\right)$ の範囲のせん断抵抗力であって, 杭が施工さ れた状態における杭周地盤の水平方向初期応力に依存すると考える. この時, $l_{n}$ 区間では杭体の周面と杭周地盤の境界面でせん断される と仮定すると， $R_{S}$ は以下のように計算できる.

$$
R_{s}=\sigma_{h 0}^{\prime} \cdot \pi \cdot D_{n} \cdot l_{n} \cdot \tan \delta
$$

ここで， $\sigma_{h 0}^{\prime}$ : 杭周地盤の水平方向初期応力

$D_{n} \quad$ : 節部径

$\delta \quad$ : 杭周面と杭周地盤の境界面でのせん断抵抗角

\section{b. 節部傾斜面の支持力}

節下部の傾斜面上端の軸力 $N_{m}$ と節下端の軸力 $N_{u}$ の差が節部傾斜 面から地盤に伝達される。この力 $\left(N_{m}-N_{u}\right)$ は, 図 6 に示す節部傾斜面 に接続する三角形 $\mathrm{abc}$ の環状の土塊（以下，環状楔）を介して，下 面 $(\mathrm{b} \sim \mathrm{c})$ の支持力 $R_{t b}$ と側面 $(\mathrm{a} \sim \mathrm{c})$ の支持力 $R_{t s}$ で抵抗すると考 える. 図 6 の右側にはこのときの節部傾斜面の力のつり合い状態を 描いた. 水平力 $H$ は半径方向の力であって, 一般では $\mathrm{a} \sim \mathrm{c}$ 面の垂 直応力と $b{ }_{c}$ 面のせん断応力の和と表わされるが，本論文では $b$ 〜 c 面のせん断応力を無視した。 その理由は, b 点が杭軸部の表面 に接触している状況は，パイルキャップを有する杭頭に近い杭周面 部は鉛直荷重に対してほとんど抵抗しない実測例 ${ }^{8)}$ や解折例 ${ }^{9)}$ と類 似であると考えたことによる。なお，H は全円周で作用するのでつ り合い条件を満足する. $M_{s}$ は円筒面の $R_{t s}$ および $M_{n}$ は $l_{t 2}$ 間の軸力差 $N_{m}-N_{u}$ を節部傾斜面に移動させたことによって発生するモーメント であり，いずれも全円周でつり合い条件を満足する. 
b-1＼cjkstart環状楔の底面に生じる鉛直力による支持カ : $R_{t b}$

$R_{t b}$ は節部と軸部間の円環状の鉛直投影面に作用する支圧抵抗力 に等しいとして，下記のように計算する。

$$
R_{t b}=q_{t b} \cdot \pi \cdot\left(D_{n}{ }^{2}-D_{s}{ }^{2}\right) / 4
$$

ここで， $D_{s} \quad$ : 軸部径

$$
q_{t b} \quad: \text { 節部底面の支持力度 }
$$

b-2 環状楔の側面に生じる水平カによる支持カ : $R_{t s}$

$R_{t s}$ は節部傾斜面の水平投影面となる円筒面に作用するせん断抵 抗力であって, 次式で得られる.

$$
\begin{aligned}
R_{t s} & =H \cdot \tan \phi \\
& =R_{t b} \cdot \tan \left(90^{\circ}-\theta_{2}-\delta\right) \cdot \tan \phi
\end{aligned}
$$

ここで， $H$ : 節部傾斜面から水平に伝達する力

$\theta_{2} \quad$ : 節部下傾斜角度

$\delta \quad$ : 節傾斜部と環状楔の境界面でのせん断抵抗角

$\phi$ : 杭周面地盤のせん断抵抗角 (内部摩擦角)

\section{3. 節部抵抗力 $\left(R_{s}, R_{t b}, R_{t s}\right)$ 算定における諸常数の設定方法 \\ 3. $1 R_{s}$ 算定における諸常数}

\section{（1）せん断抵抗角 $\delta$ の評価}

(2) 式に示寸節部 $l_{n}$ 区間における杭周面摩擦力の評価に際して, 杭の周面摩擦力が排水条件で発生すると考えれば, 杭周面地盤が砂 質土および粘性土にかかわらず, 最大杭周面摩擦力度 $f_{\text {max }}$ は(5)式で 与えられる。

$$
\begin{aligned}
f_{\max } & =\sigma_{h 0}^{\prime} \cdot \tan \delta \\
& =K \cdot \sigma_{z 0}^{\prime} \cdot \tan \delta
\end{aligned}
$$

ここで, $f_{\max }$ : 最大杭周面摩擦力度

$$
\begin{aligned}
K & : \text { 土圧係数 } \\
\sigma_{z 0}^{\prime} & \text { : 杭周地盤の鉛直方向初期応力（有効上載圧） }
\end{aligned}
$$

緩い砂質土や軟らかい粘性土の場合には, 杭表面からわずかに離 れた地盤内でせん断破壊が発生するので, 一般的には土の有効内部 摩擦角 $\phi^{\prime}$ 用いて $\delta=\phi^{\prime}$ とできる. 一方, 硬い粘性土や本論文で対 象とするような密な砂質土の場合には, 杭周面と地盤の境界で滑る 可能性が高くなる. この時の摩擦角として, 鋼杭で $\delta=(1 / 2 \sim 3 / 4)$ $\phi$, 既製コンクリート杭で $\delta=(3 / 4 \sim 1) \phi$ が日本建築学会の建築基 礎構造設計規準 ${ }^{10)}$ に示されている. それに対して, 実大の場所打ち コンクリート杭に関するデータは極めてそしいのが現状である. 地 盤にコンクリートを打設した場合として, Potyondy ${ }^{11)}$ は密な飽和砂 の地表面にコンクリートを打設した場合として,$\delta=0.9 \phi$ を提示し ている. しかし，場所打ちコンクリート杭の場合には，施工時に安 定液を使用することから, 孔壁に $2 \mathrm{~mm}$ 程度の薄い膜(マッドケーキ) が形成される ${ }^{12)}$. マッドケーキの存在は摩擦角を低下させる作用と なることが推察される。これらの状沉を考慮して, 鋼杭と既製コン クリート杭の平均的な值である $\delta=(3 / 4) \phi$ を仮定することにした.

\section{(2) 土圧係数 $K$ の評価}

杭頭部の載荷直前における杭周面に作用寸る水平方向初期応力 $\sigma_{h 0}^{\prime}$ は, 杭種・施工法や地盤の過圧密比によって影響を受けると考

\begin{tabular}{|c|c|c|c|c|c|c|c|c|c|c|c|c|}
\hline No & $\begin{array}{l}\text { 参考 } \\
\text { 文献 }\end{array}$ & 地層 & 杭径 & $\begin{array}{l}\text { 深度 } \\
\text { (屬) }\end{array}$ & 層厚 & $\begin{array}{l}\text { 平均 } \\
N \text { 値 }\end{array}$ & $\begin{array}{c}\text { 鉛直 } \\
\text { 有効 } \\
\text { 応力 } \\
\\
\sigma^{\prime} z \\
\left(\mathrm{kN} / \mathrm{m}^{\prime \prime}\right)\end{array}$ & $\begin{array}{c}\text { 内部 } \\
\text { 摩擦 } \\
\text { 第 } \\
\phi \\
\left(^{\circ}\right)\end{array}$ & $\begin{array}{c}\text { 世九断 } \\
\text { 抵抗角 } \\
\delta \\
\left(^{\circ}\right)\end{array}$ & 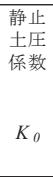 & $\begin{array}{l}\text { 最大 } \\
\text { 周面 } \\
\text { 摩擦 } \\
\text { 力度 } \\
\\
\text { fmax } \\
\left(\mathrm{kN}^{2} \mathrm{~m}^{3}\right)\end{array}$ & $\begin{array}{c}f \operatorname{fmax} \text { から } \\
\text { 算出した } \\
\text { 土圧係数 } \\
\quad K\end{array}$ \\
\hline \multirow{2}{*}{$1^{*}$} & \multirow{2}{*}{$\operatorname{SITE~A~}^{16)}$} & $\begin{array}{l}\text { 細砂 } \\
\end{array}$ & 2.5 & 18.8 & 8.8 & 21 & 139.0 & 35.5 & 26.6 & 0.42 & 84.4 & 1.21 \\
\hline & & 細砂 & 2.5 & 22.8 & 4.0 & 19 & 171.0 & 34.5 & 25.9 & 0.43 & 71.6 & 0.86 \\
\hline \multirow[t]{2}{*}{2} & \multirow[t]{2}{*}{ SITE $B^{17)}$} & $\begin{array}{l}\text { 細砂 } \\
\end{array}$ & 1.0 & 25.0 & 4.0 & 22 & 191.0 & 36.0 & 27.0 & 0.41 & 100.0 & 1.03 \\
\hline & & 細砂 & 1.0 & 26.0 & 4.0 & 22 & 196.0 & 36.0 & 27.0 & 0.41 & 100.0 & 1.00 \\
\hline \multirow[t]{6}{*}{3} & \multirow[t]{6}{*}{ SITE C ${ }^{18)}$} & 細砂 & 1.09 & 2.2 & 1.5 & 25 & 38.9 & 37.4 & 28.0 & 0.39 & 191.0 & 9.23 \\
\hline & & 砂磔 & 1.09 & 3.7 & 1.5 & 38 & 58.1 & 42.6 & 31.9 & 0.32 & 382.0 & 10.55 \\
\hline & & 砂碩 & 1. 09 & 5.2 & 1.5 & 50 & 76.1 & 46.6 & 35.0 & 0.27 & 294.0 & 5. 52 \\
\hline & & 細砂 & 1. 09 & 2. 2 & 1.5 & 25 & 38.1 & 37.4 & 28.0 & 0.39 & 153.0 & 7. 55 \\
\hline & & 砂磔 & 1. 09 & 5.2 & 1.5 & 35 & 68.1 & 41.5 & 31.1 & 0.34 & 340.0 & 8. 28 \\
\hline & & 砂磉 & 1. 09 & 6.7 & 1.5 & 50 & 81.6 & 46.6 & 35.0 & 0.27 & 191.0 & 3. 35 \\
\hline \multirow[t]{2}{*}{4} & \multirow[t]{2}{*}{ SITE D ${ }^{19)}$} & 細砂 & 1.5 & 16.5 & 8.9 & 34 & \begin{tabular}{|l|}
123.1 \\
\end{tabular} & 41.1 & 30.8 & 0.34 & 68.0 & 0.93 \\
\hline & & 細砂 & 1.5 & 18.8 & 2.3 & 28 & 141.5 & 38.7 & 29.0 & 0.38 & 176.0 & 2. 24 \\
\hline \multirow[t]{2}{*}{$5^{*)}$} & \multirow[t]{2}{*}{ SITE E E) } & 細砂 & 1.2 & 22.0 & 10.0 & 30 & 155.0 & 39.5 & 29.6 & 0.36 & 78.4 & 0.89 \\
\hline & & 砂磻 & 1.2 & 48.0 & 8.0 & 50 & 358.0 & 46.6 & 35.0 & 0.27 & 205.8 & 0.82 \\
\hline \multirow[t]{5}{*}{$6^{*)}$} & \multirow[t]{5}{*}{ SITE F $\mathrm{F}^{21)}$} & 細砂 & 1.2 & 14.5 & 3.5 & 35 & \begin{tabular}{|l|}
138.0 \\
\end{tabular} & 41.5 & 31.1 & 0.34 & 58.8 & 0.71 \\
\hline & & 砂碯 & 1.2 & 19.5 & 5.0 & 50 & 188.0 & 46.6 & 35.0 & 0.27 & 99.0 & 0.75 \\
\hline & & 砂磞 & 1.2 & 23.0 & 3.5 & 42 & 219.5 & 44.0 & 33.0 & 0.31 & 126.4 & 0.89 \\
\hline & & 細砂 & 1.2 & 25.0 & 2.0 & 40 & 237.5 & 43.3 & 32.5 & 0.31 & 169.5 & 1. 12 \\
\hline & & 砂碩 & 1.2 & 27.0 & 2.0 & 50 & 257.5 & 46.6 & 35.0 & 0.27 & 182.3 & 1.01 \\
\hline \multirow[t]{2}{*}{7} & \multirow[t]{2}{*}{ SITE G ${ }^{22)}$} & 砂碩 & 1.2 & 9.0 & 3.0 & 46 & 121.0 & 45.3 & 34.0 & 0.29 & 343.0 & 4. 20 \\
\hline & & 砂碩 & 1.0 & 9.0 & 3.0 & 46 & 121.0 & 45.3 & 34.0 & 0.29 & 294.0 & 3.60 \\
\hline
\end{tabular}
えられる.これは，(5)式における土圧係数 $K$ の評価に際して極めて 重要な問題である. 打込み杭や回転貫入杭のような排土杭

(Displacement pile) では, 静止土圧係数 $K_{0}$ よりも大きい $K$ が得ら れているはずであるが, 実杭の載荷試験による杭周面摩擦力は場所
表 1 杭の周面抵抗に関する横力係数 $K_{L}$ (文献 ${ }^{14)}$ )

\begin{tabular}{l|c}
\hline \multicolumn{1}{c|}{ 提唱者 } & $K_{L}$ \\
\hline Prandt1 (1920), Jaky (1948) & $K_{0}(0.5 \sim 1.0)$ \\
Krey (1936), Myere-Ptere (1947) & 1.0 \\
Dorr (1922) & $1+\tan ^{2} \phi$ \\
Benabencq (1911), Bennell (1931) & $K_{p}$ \\
\hline ここに $K_{0}:$ 静止土圧係数, $\phi:$ 内部摩擦角, $K_{p}:$ 受働土圧係数
\end{tabular}

表 2 杭の載荷試験結果と土圧係数 $K$

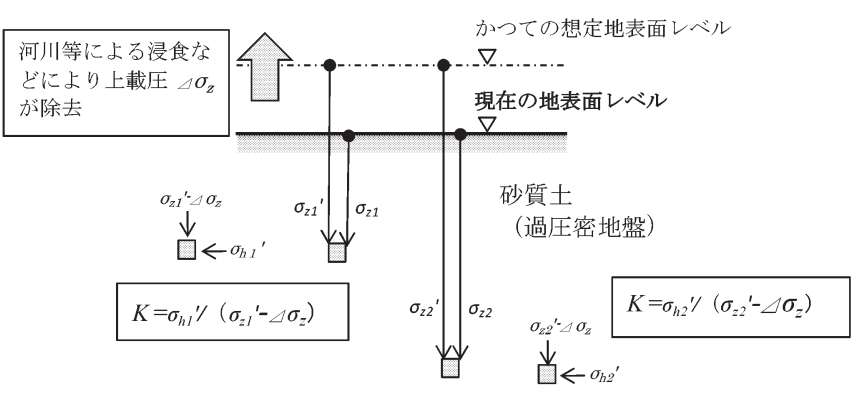

（1）浅い場合（2）深い場合

図 7 砂質土における過圧密比の影響の概念図

打ち杭や埋込み杭のような非排土杭（Non-displacement pile）よりも 小さい場合が多い.これについては種々の理由が指摘されているが， 場所打ち杭ではコンクリート打設による流動圧が掘削に伴う応力解 放を上回る現象も実測 ${ }^{13)}$ されている. 文献 ${ }^{14)}$ には, 表 1 に示寸砂地 盤における杭の周面抵抗に関する横力係数 $K_{L}$ が掲載されている. 静 止土圧係数 $K_{0}$ よりも小さいものから受働土圧係数 $K_{P}$ に至るまで 種々の提唱值が紹介されていることから，対象とする地盤や施工条 件によって大きく変化するものと考えられる.

図 7 は砂質土を対象とした土圧係数に与える過圧密比の影響の概 念図である. 水期と間水期の繰返しによる海面（地下水位）の低下 や上昇などにより形成された過圧密地盤では，かつての想定地表面 レベルから河川等による浸食などにより上載圧が除去されても，一 般に水平方向応力 $\sigma_{h}{ }^{\prime}$ の減少が小さいと考えられる. また, 過圧密地 盤以外でも地表面の土圧係数が大きくなる現象が小林ら ${ }^{15)}$ の文献 
でも示されている.これらのことから, 埋立て地盤などの特殊なケ 一スを除く国内の一般地盤の土圧係数 $K$ の值は, 深度が深くなるに つれて減少して静止土圧係数 $K_{0}$ に漸近する性質をもつと推察され る.

以上のことから, 本論文では場所打ち杭に対して実施された多数 の載荷試験結果を収集分析して, 土圧係数が地表面から深さ方向に 減少する性質を組み込んだ $K$ 值の算定式を新らたに誘導する.

既往の載荷試験結果については, 既に文献 ${ }^{16)}$ 22) で報告されてい る場所打ち杭の載荷試験を行った 7 現場 21 ケ所の砂質土と砂碩質 土の試験データを収集整理した. 表 2 は試験サイト一覧の載荷試験 結果をまとめたもので, 通常の鉛直載荷試験結果の他に先端載荷試 験が含まれている．№.3のオールケーシング工法を除いて，全てア ースドリル工法で施工している. 最大周面摩擦力度の算出は, 対象 とする地層の上下に設置されているひずみ計に基づいている．この 時の杭のヤング係数は杭頭付近などの軸力が明確なひずみ測定值や 試験杭から採取したコアの圧縮試験などから求め, 杭体の周面積は 設計軸径寸法と仮定した。

また, 対象とする砂質土近傍の粘性土の一軸圧縮強さ $q_{u}$ が示され ているサイトについて, 過圧密比 OCR を推定した. 寸なわち, 文 献 ${ }^{23)}$ で得られている圧密降伏応力 $P_{c}=(1.5 \sim 3.0) \quad q_{u}$ と鉛直有効応 力 $\sigma_{z}^{\prime}$ の関係から, SITE A の深度 $7 \mathrm{~m}$ 付近の粘性土は $\mathrm{OCR}=4.2 \sim$ 8.4, SITE B の深度 $19 \mathrm{~m}$ 付近の粘性土は $\mathrm{OCR}=1.3 \sim 2.7$ となる. いずれも粘性土の OCR であるが，近傍の砂質土も同程度の過圧密 地盤であると考えられる.

表中の鉛直有効応力 $\sigma_{z}{ }^{\prime}$ は, 単位体積重量 $\gamma$ と地盤柱状図に記載さ れた地下水位に基づいて算出した。 また静止土圧係数 $K_{0}$ は, Jaky $\left(K_{0}=1-\sin \phi\right)$ の式に, 建築分野で一般に使用される $(\phi=\sqrt{20 N}+15)$ より求めたせん断抵抗角を使用した.

図 8 は，以上の条件を設定した上で，(5)式で逆算した場所打ち杭 の土圧係数 $K$ を鉛直有効応力 $\sigma_{\mathrm{z}}{ }^{\prime}$ の関係でプロットしたものである. それによると， $\sigma_{\mathrm{z}}{ }^{\prime}=150 \mathrm{kN} / \mathrm{m}^{2}$ 付近から $50 \mathrm{kN} / \mathrm{m}^{2}$ 付近一小さくなるの に伴って $K$ が急増している. 図中には静止土圧係数 $K_{0}$ も示してい るが， $K$ は $\sigma_{\mathrm{z}}{ }^{\prime}$ が大きくなるに伴って $K_{0}$ に漸近する傾向を示してい る.これらの分布傾向に基づいて $\sigma_{\mathrm{z}}{ }^{\prime}=0$ の地表面では $K$ は無限大と なり， $\sigma_{\mathrm{z}}{ }^{\prime}=\infty$ では $K=K_{0}$ となるべキ関数 $\left(\mathrm{y}=\mathrm{ax}{ }^{-\mathrm{b}}+\mathrm{c}\right)$ を用いて，杭 の周面における土圧係数 $K$ を鉛直有効応力 $\sigma_{\mathrm{z}}{ }^{\prime}\left(\mathrm{kN} / \mathrm{m}^{2}\right)$ の関数とす る次式を構築した。 なお, 下式の適用範囲は, 表 2 より洪積層の $N$ 值 20 以上の砂質土とする.

$$
\begin{aligned}
& K=K_{0}+\left(\sigma_{\mathrm{z}}{ }^{\prime} / 150\right)^{-2.26} \\
& K_{0}=1-\sin \phi: \text { 静止土圧係数 } \\
& \phi=\sqrt{20 N}+15
\end{aligned}
$$$$
\text { ここで, } K: \text { 場所打ち杭の周面における土圧係数 }
$$

\section{3. $2 R_{t b}$ 算定における諸常数}

(3)式における節部と軸部間の円環状の鈶直投影面に作用する支 圧抵抗力の考え方は, 場所打ち杭の載荷試験結果と先端地盤の $N$ 值 の関係を統計処理した経験的な方式に基づくことにした。 その理由 は，杭の先端支持力に関する理論式がこれまでにいくつか提案され ているものの, 精度的な問題から実務面ではほとんど適用されてい ないためである.ただし，現行の建築基礎構造設計指針 ${ }^{24)}$ に示され

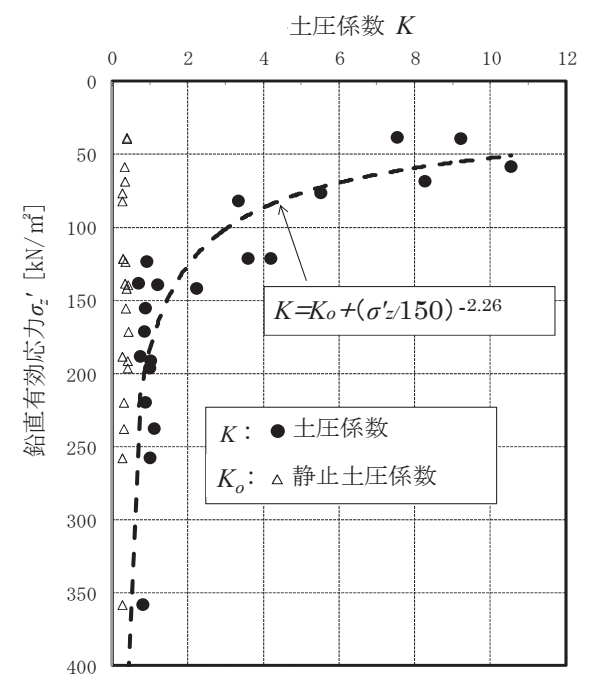

図 8 土圧係数 $K$ と鉛直有効応力 $\sigma_{\mathrm{z}}{ }^{\prime}$ の関係

ている場所打ち杭の先端支持力度 $q_{p}=100 \cdot N$ は, 杭先端面から 1.0 $\sim 1.5 m$ 程度浅い深度での杭体軸力に基づいたものであり, 杭先端面 からの軸力計測深度までの周面摩擦抵抗力も含まれている.

そこで, 本論文では場所打ち杭の杭先端載荷試験結果から杭先端 近傍の周面摩擦力を分離する考察がなされた文献 ${ }^{25}$ を整理して, 通 常の先端支持力度 $q_{p}$ (図中の白抜き印〉) および杭先端面のみの支 持力度 $q_{b}$ (図中の黒塗り印○）と $N$ 值（杭先端面から下へ杭直径ま での範囲）の関係を図 9 に示した。それによると， $q_{b}$ が $q_{p}$ より明ら かに小さい傾向がみられる.

以上のことから， $q_{b}$ と $N$ 值の相関性に基づき, 本論文では(3)式の $q_{t b}$ の支持力係数を $\alpha=75$ と設定する. $N$ 值の採用範囲は，押込み力 算定時では節部傾斜面の下端より $D_{n}$ までの範囲，引抜き力算定時 では節部傾斜面の上端より $D_{n}$ までの範囲とした.

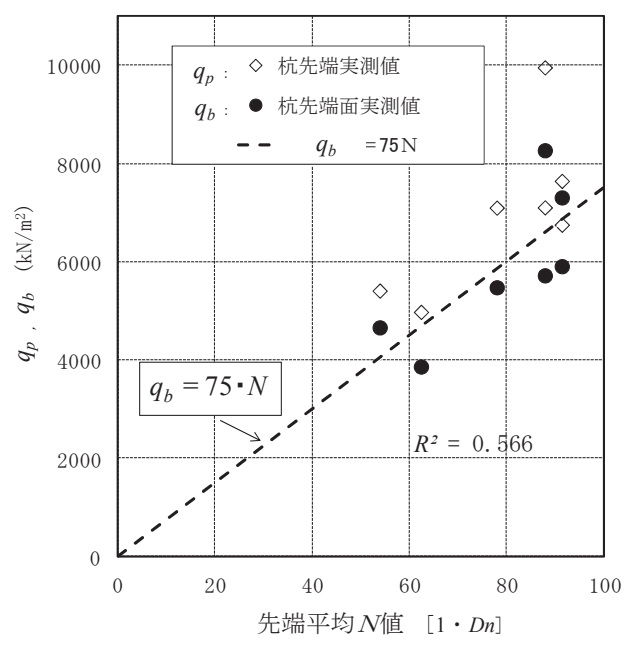

図 9 杭の先端面支持力度と $N$ 值の関係

\section{3. $3 R_{t s}$ 算定における諸常数}

節部傾斜面の水平投影面となる円筒面に作用するせん断抵抗力 $R_{t s}$ を算定する(4)式中においては，(3)式で計算される $R_{t b}$ の值を使用 寸る. また, 傾斜面のせん断抵抗角 $\delta$ は 3.1 節の $R_{s}$ 算定に用いた值 と同様の $\delta=(3 / 4) \phi$ を設定する. 


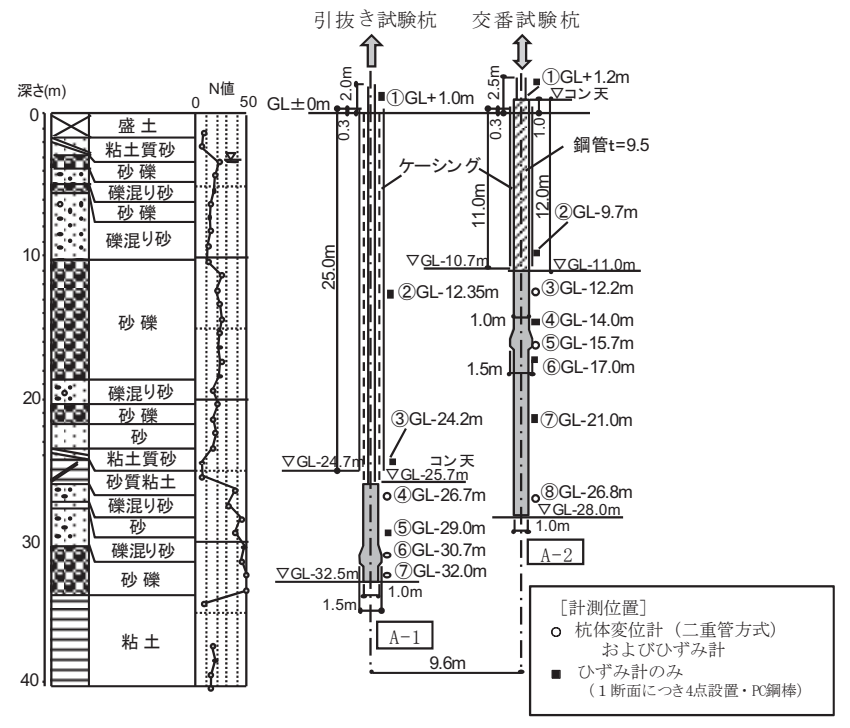

(a)サイト A

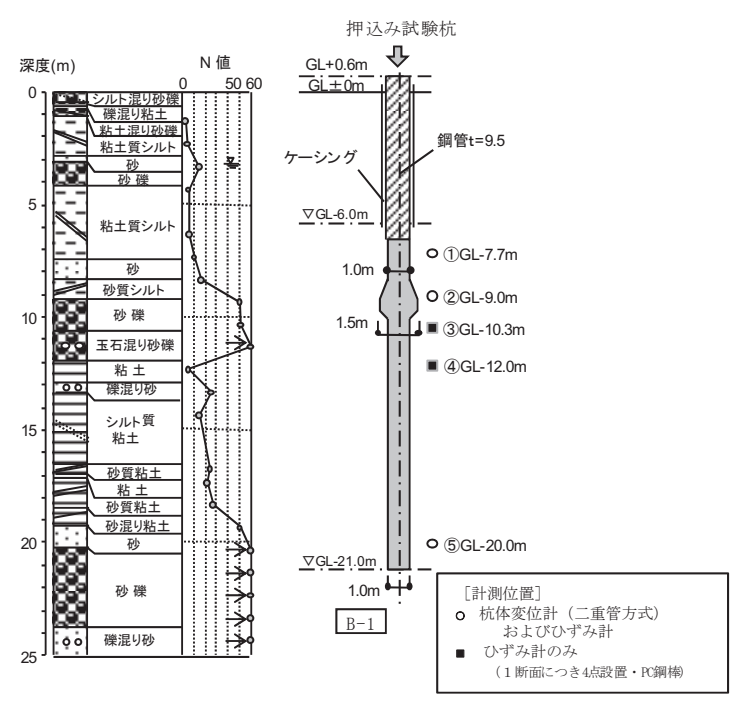

(b)サイト B

図 10 試験地盤と試験体の概要

表 3 試験体の仕様および計画最大荷重

\begin{tabular}{|c|c|c|c|c|c|c|c|c|c|}
\hline 試験体 & \begin{tabular}{|c|} 
軸部径 \\
$D_{s}$ \\
$(\mathrm{~m})$ \\
\end{tabular} & $\begin{array}{c}\text { 節部径 } \\
D_{n} \\
(\mathrm{~m}) \\
\end{array}$ & $\begin{array}{l}\text { 杭長 } \\
\text { (m) } \\
\end{array}$ & $\begin{array}{l}\text { 節部 } \\
\text { 深度 } z \\
(G L-m) \\
\end{array}$ & $\begin{array}{l}\text { 載荷 } \\
\text { 方向 }\end{array}$ & $\begin{array}{c}\text { 節部 } \\
\text { 傾斜角 } \\
\theta_{1}, \theta_{2} \\
\end{array}$ & $\begin{array}{l}\text { 定着 } \\
\text { 地盤 }\end{array}$ & $\begin{array}{l}\text { 平均 } \\
N \text { 値 }\end{array}$ & $\begin{array}{c}\text { 計画 } \\
\text { 最大荷重 } \\
(\mathrm{kN}) \\
\end{array}$ \\
\hline A-1 & 1.0 & 1.5 & 6.3 & 31.2 & 引き & $\theta_{1}=20^{\circ}$ & 砂硫土 & 44 & 10000 \\
\hline A-2 & 1.0 & 1.5 & 17.0 & 15.7 & 引き & $\theta_{1}=20^{\circ}$ & 砂碩土 & 23 & 10000 \\
\hline B-1 & 1.0 & 1.5 & 15.0 & 9.5 & 押し & $\theta_{2}=45^{\circ}$ & 砂硫土 & 50 & 28000 \\
\hline
\end{tabular}

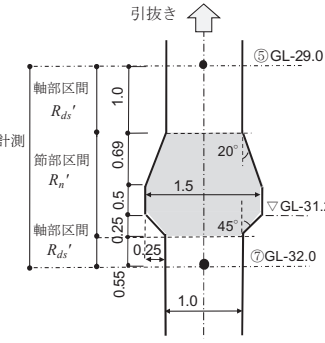

(a)A-1

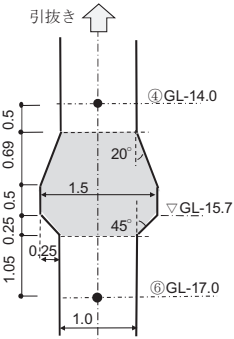

(b)A-2

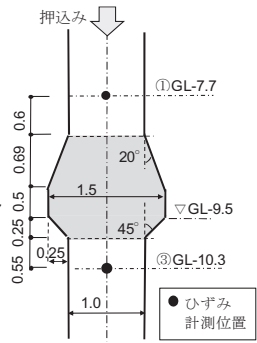

(c)B-1

図 11 節部形状とひずみ計測位置（単位：m）

引張り軸力 $(\mathrm{kN})$

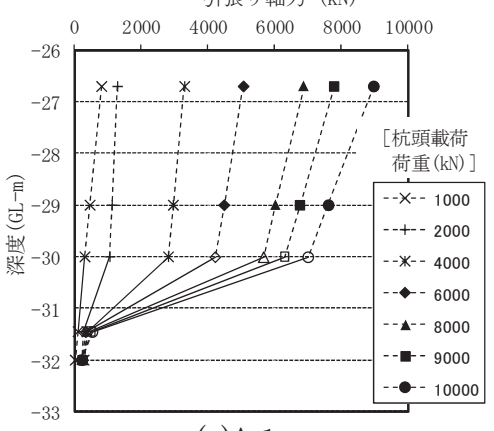

(a) $\mathrm{A}-1$

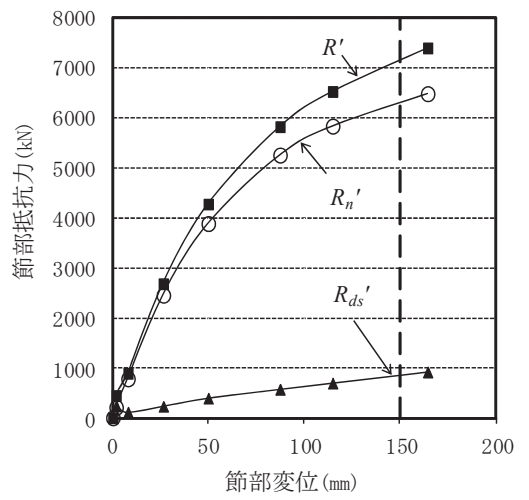

(a) A-1

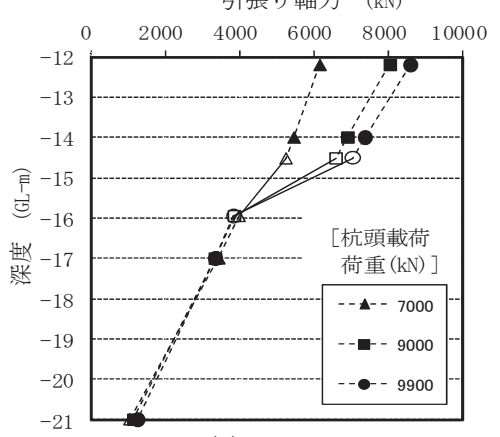

(b)A-2

図 12 節部近傍の軸力分布

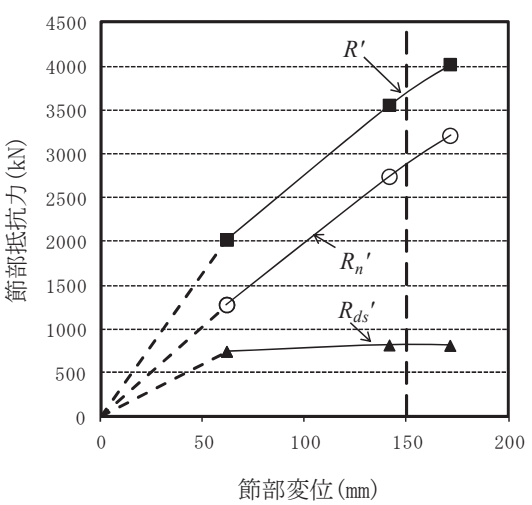

(b)A-2

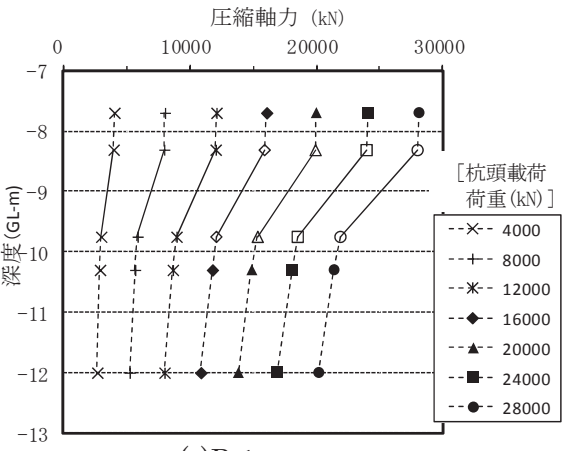

(c)B-1

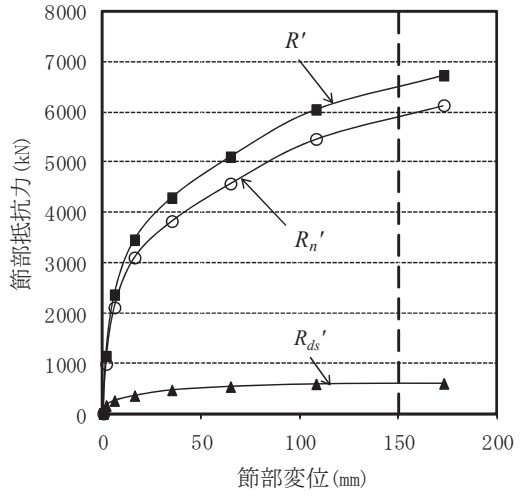

(c)B-1

図 13 節部抵抗力〜節部変位の関係 
表 4 節部抵抗力の計算值の結果

\begin{tabular}{|c|c|c|c|c|c|c|c|c|c|c|c|c|c|c|}
\hline \multirow[b]{2}{*}{ 試験体 } & \multicolumn{4}{|c|}{ 節部形状 } & \multicolumn{6}{|c|}{ 地盤の諸定数 } & \multicolumn{4}{|c|}{ 計算值 } \\
\hline & $\begin{array}{c}\text { 軸部径 } \\
D_{s} \\
\text { (m) }\end{array}$ & $\begin{array}{c}\text { 節部径 } \\
D_{n} \\
\text { (m) }\end{array}$ & $\begin{array}{l}\text { 節部 } \\
\text { 深度 } z \\
\text { GL-(m) } \\
\end{array}$ & $\begin{array}{c}\text { 節部傾斜 } \\
\text { 角度 } \theta_{1}, \theta_{2} \\
\left({ }^{\circ}\right)\end{array}$ & $\begin{array}{l}\text { 定着 } \\
\text { 地盤 }\end{array}$ & $\begin{array}{l}\text { 平均 } \\
N \text { 値 }\end{array}$ & \begin{tabular}{|c} 
内部 \\
摩摖角 $\phi$ \\
$\left({ }^{\circ}\right)$ \\
\end{tabular} & $\begin{array}{c}\text { せん断 } \\
\text { 抵抗角 } \delta \\
\left.{ }^{\circ}\right) \\
\end{array}$ & $\begin{array}{c}\text { 鉛直有効 } \\
\text { 応力 } \sigma_{z}{ }^{\prime} \\
\left(\mathrm{kN} / \mathrm{m}^{2}\right) \\
\end{array}$ & $\begin{array}{c}\text { 土圧 } \\
\text { 係数 } K\end{array}$ & $\begin{array}{c}R_{s} \\
(\mathrm{kN}) \\
{\left[R_{s} / R_{n}\right]} \\
\end{array}$ & $\begin{array}{c}R_{t b} \\
(\mathrm{kN}) \\
\\
{\left[R_{t b} / R_{n}\right]} \\
\end{array}$ & \begin{tabular}{|c|}
$R_{t s}$ \\
$(\mathrm{kN})$ \\
{$\left[R_{t s} / R_{n}\right]$} \\
\end{tabular} & $\begin{array}{c}R_{n} \\
(\mathrm{kN}) \\
{\left[R_{n} / R_{n}\right]} \\
\end{array}$ \\
\hline A-1 & 1.0 & 1.5 & 31.2 & $\theta_{1}=20$ & 砂磦土 & 44 & 44. 7 & 33.5 & 300 & 0.50 & $\begin{array}{c}234 \\
{[0.04]}\end{array}$ & $\begin{array}{l}3234 \\
{[0.56]}\end{array}$ & $\begin{array}{l}2356 \\
{[0.40]}\end{array}$ & $\begin{array}{l}5824 \\
{[1.00]}\end{array}$ \\
\hline$A-2$ & 1.0 & 1.5 & 15.7 & $\theta_{1}=20$ & 砂碩土 & 23 & 36.4 & 27.3 & 150 & 1. 41 & $\begin{array}{l}257 \\
{[0.09]}\end{array}$ & $\begin{array}{l}1691 \\
{[0.57]}\end{array}$ & $\begin{array}{l}1036 \\
{[0.34]}\end{array}$ & $\begin{array}{l}2984 \\
{[1.00]}\end{array}$ \\
\hline B-1 & 1.0 & 1.5 & 9.5 & $\theta_{2}=45$ & 砂磕土 & 50 & 46.6 & 35.0 & 100 & 2. 77 & $\begin{array}{c}456 \\
{[0.09]}\end{array}$ & $\begin{array}{l}3675 \\
{[0.76]}\end{array}$ & $\begin{array}{c}689 \\
{[0.15]}\end{array}$ & $\begin{array}{l}4820 \\
{[1.00]}\end{array}$ \\
\hline
\end{tabular}

\section{4. 節部抵抗力に関する評価法の検証}

\section{1 節付き杭の原位置載荷試験 ${ }^{1)}$, 2)}

\section{（1）試験地盤と試験体の概要}

原位置載荷試験は図 10 に示寸 2 ヶ所（サイト A, サイトB）で実 施した。 サイト $\mathrm{A}$ は, 大阪平野の上町台地の北側の旧淀川沿いの天 満地区である. 地盤は GL-10m 以深に $N$ 值 20 程度の砂砂質の沖積層 が堆積しており, GL-26m 付近から天満砂礫層に相当寸る洪積層が出 現している. サイト B は, 大阪平野の北東に位置する淀川低地の地 区である. 地盤は GL- $9 \mathrm{~m}$ 付近までが粘土質の沖積層で, GL-10m 付 近に $N$ 值 50 程度, 厚さ $3 \mathrm{~m}$ 程度の砂礫質の洪積層が出現している. その下には $N$ 值 20 程度のシルト質粘土層が堆積しており, GL-19m 付近から $N$ 值 50 以上の洪積砂碩層（大阪層群）が現れる.

試験体は表 3 に示す 3 体である. 全ての試験体はアースドリル工 法を用いた節付き杭の施工手順 ${ }^{1)}$ で施工した。 各々の試験体の特徴 を以下に示寸．なお，いずれの試験体も節部上傾斜角度は $20^{\circ}$ ，下 傾斜角度は $45^{\circ}$ である。

-A-1 試験体：杭先端に近い密な砂鿬を有する深度（節部深度： GL-31.2m）での引抜き試験であって, 節部にできる限り大きな荷重 が伝達するように地表面から $26 \mathrm{~m}$ の間はコンクリートを打設せず引 張り用の PC 鋼棒のみとし, ゲル化させた安定液を充填したケーシ ングを設置した。杭の実長は $6.8 \mathrm{~m}$ である.

- A-2 試験体 : $N$ 值 20 30 程度の中間砂礫層 (節部深度: GL- $15.7 \mathrm{~m}$ ) での交番載荷試験であって, 上記同様に節部に大きな荷重が伝達す るように，地表面から $11 \mathrm{~m}$ 付近まで二重管方式によるフリクション カットを行った。なお, 本論文では引抜き試験結果を採用している.

-B-1 試験体：比較的密な中間砂碩層（節部深度：GL-9.5m）での押 込み試験であって, 上記同様に, 地表面から $6 \mathrm{~m}$ 付近まで二重管方式 によるフリクションカットを行った。

\section{(2) 節部抵抗力の実験結果}

図 11 は 3 試験体の節部形状とその近傍のひずみ計測位置を示し たものである、節部の抵抗力を求めるには，節部上端または節部下 端から計測位置までの軸部周面による抵抗力を除去する必要がある.

図 12 は節部から上側の軸部および下側の軸部の軸力分布をそれ ぞれ直線で外挿して, 節部上端および節部下端の軸力を算定した結 果（図中の白抜き）である。それによると，節部の抵抗は上下の軸 部区間よりは明らかに大きく, 載荷の進行に伴う抵抗力の増加は軸 部のそれと同様な傾向を示している. 図 13 は節部抵抗力〜節部変位 の関係である。引抜き試験の A-1 では $50 \mathrm{~mm}$ 変位付近から剛性が低

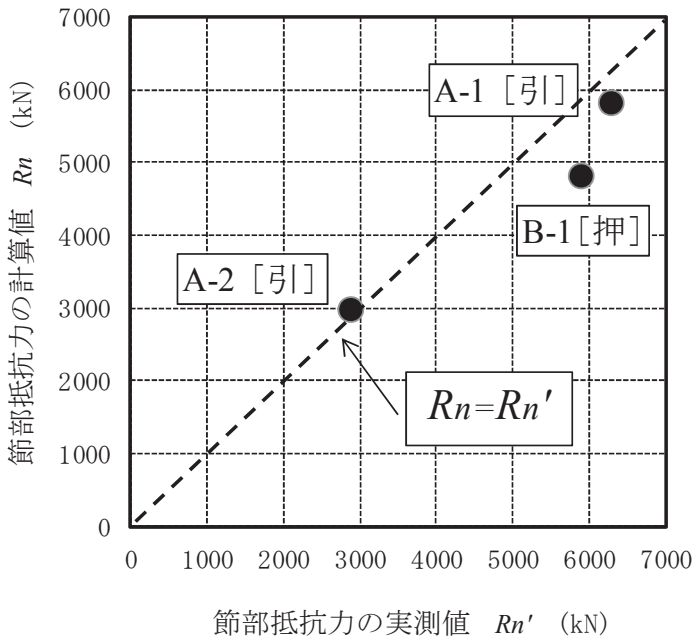

図 14 節部抵抗力の計算值と実測值との関係

下している．この原因は，引抜き試験中の繰返し載荷による節部変 位の増加による影響と考えられる ${ }^{1)}$ 。 A-2 の交番載荷試験では軸部 抵抗力 $R_{d s}{ }^{\prime}$ が少なくとも $50 \mathrm{~mm}$ 変位時点で極限に達しているのに対し て, 節部抵抗力 $R_{n}{ }^{\prime}$ は節部径の $10 \%$ 変位時点でも直線的に増加して いる．このことから，押し引き荷重を受ける場合は，軸部の周面摩 擦力の低下が顕著であることが示唆される．B-1 の押込み載荷試験 では，かなり小さな変位で剛性低下が生じている。この原因は，軸 部抵抗力 $R_{d s}{ }^{\prime}$ が初期の荷重段階の小さな变位（20mm 程度）で極限に 達していることが影響と考えられる。

節部径の $10 \%$ 変位時点（变位 $150 \mathrm{~mm}$ ）を極限支持力とみなすと, 節部抵抗力の実測值 $R_{n}{ }^{\prime}$ は, A-1 :6, 281kN, A-2 : 2, 873kN, B-1 :5, 888kN となった。これらの值は，ひずみ計設置区間の軸力差 $R^{\prime} の ~ 75 \sim 90 \%$ 程度であった。

\section{2 本論文の計算値と載荷試験実測值の比較}

上記の 3 試験体について, 本論文で構築した節部抵抗力の評価方 法による計算值を，表 4 に示した。節部傾斜角度が $20^{\circ}$ である A-1 および $\mathrm{A}-2$ をみると。節部抵抗力 $R_{n}$ に占める $R_{t b}$ 成分は $55 \%$ 程度で あること， $R_{t s}$ 成分が $40 \%$ 程度であることがわかる．また， $K$ が大き くなるに伴い $R_{s}$ が大きくなることがわかる. それに対して, 節部傾 斜角度が $45^{\circ}$ である B-1 の節部抵抗力に占める $R_{t b}$ 成分は $75 \%$ 程度 にもなること， $R_{t s}$ 成分が $15 \%$ 程度となることがわかる. 
図 14 は表 4 の計算值 $R_{n}$ と実測值 $R_{n}{ }^{\prime}$ をプロットしたものである. 試験体は 3 体であるが, 節部傾斜角度が $20^{\circ}$ および $45^{\circ}$ の両ケース 共に, 計算值と実測值の比は $0.82 \sim 1.04$ と良く近似することが明ら かになった。本論文で構築した節部抵抗力の評価方法は比較的簡便 であり，実務設計でも有効であると考えられる。

\section{5.まとめ}

押込夕荷重および引抜き荷重が作用する節付き場所打ち杭に関し て, 以下に示す(1)〜 (3)の成分を累加する新たな節部抵抗力の実用的 な評価方法を構築した。

(1). 節部円筒面のせん断抵抗力 $R_{s}$ : 既往の場所打ち杭の鉛直載荷試 験結果を収集整理して, 過圧密状態を考慮した新たな土圧係数 $K$ の深度分布算定式を誘導した後, 節部周面地盤の水平方向初期応 力 $\sigma_{h 0}^{\prime}$ とせん断抵抗角 $\delta$ に基づいて $R_{s}$ を計算した。

(2). 環状楔の底面の抵抗力 $R_{t b}$ : 節部突出幅部分（円環断面）の支圧 抵抗力であって, 通常の場所打ち杭 (円形断面) の先端支持力か ら杭周面摩擦抵抗分を差し引いた先端面抵抗と同様とみなして, 標準貫入試験の $N$ 值に基づいて $R_{t b}$ を計算した.

(3). 環状楔の側面のせん断抵抗力 $R_{t s}$ : 節部傾斜面に接続する環状楔 に発生する水平力 $H$ と地盤の内部摩擦角 $\phi$ に基づいて $R_{t s}$ を計算 した.

上記(1)〜 (3)で計算される節部の全抵抗力を, 節部傾斜角度が $20^{\circ}$ および $45^{\circ}$ の実大規模の載荷試験結果と比較した. 計算値と実測值 は近似することから, 本論文で構築した節部抵抗力の評価方法は, $20^{\circ} \sim 45^{\circ}$ 程度の節部傾斜角度を有する節付き場所打ち杭に関して 適用できるものと考える。

\section{参考文献}

1）須藤敏巳, 渡邊康司, 茶谷文雄ほか：場所打ち節付き杭の鉛直交番載荷 および引抜き試験 (その 1 その 5), 日本建築学会大会学術講演梗概集, B-1 分冊, pp. 567-576, 2008. 8

2）須藤敏巳, 渡邉康司, 石井雄輔ほか：場所打ち節付き杭の押込み試験お よび引抜き試験（その 1〜その 4), 日本建築学会大会学術講演梗概集, B-1 分冊, pp. 613-620, 2010.9

3）平井芳雄，青木雅路：拡径部を有する場所打ちコンクリート杭の引抜き 性状に関する原位置引抜き試験, 構造工学論文集, Vol. 54B, pp. 59-66, 2008.3
4）八尾眞太郎，伊藤淳志ほか：節付き場所打ちコンクリート杭の節部底面 支持力算定式, 日本建築学会構造系論文集, 第 556 号, pp. 79-84, 2002.6

5）小椋仁志，山肩邦男，岸田英明：模型実験による節付き円筒杭の支持力 特性の検討, 日本建築学会構造系論文報告集, 第 374 号, pp. 87-97, 1987.4

6) Honda, T.,Hirai, Y.and Sato, E. : Uplift capacity of belled and multi-belled piles in dense sand, Soils and Foundations, Vol.51,No.3, pp. 483-496, June 2011

7) 平山英喜ほか: 砂中のテーパー杭の周面摩擦抵抗, 第 26 回土質工学研究 発表会, pp. 1385-1388, 1981.7

8）秋野矩之, 桑原賢司ほか : 鹿児島県庁舎新築工事の基礎工に関する解折 と実測（その 1〜その 4), 第 31 回地盤工学研究発表会, pp. 1519-1526, 1996. 7

9）土屋勉：併用(パイルド・ラフト)基礎における相互作用, 基礎工, pp21-25, 2009. 10

10）日本建築学会 : 建築基礎構造設計規準 ・同解説, pp. 282-283, 1974

11) Potyondy, J.G. : Skin Friction Between Various Soils and Construction Materials, Geotechnique, Vol.11,No.4, pp. 339-353, 1961

12）喜田大三，川地武：泥水工法における泥水管理装置に関する研究（第 25 報），大林組技術研究所所報，pp. 110-114， 1980

13）地盤工学会 : 入門シリーズ 22 土圧入門, pp. 198-206, 1997

14）日本建築学会 : 建築基礎構造設計規準 ・同解説, p. 314, 1974

15）小林勝巳，大西靖和 : 有効応力に基く砂地盤における場所打ち杭の周面 摩擦抵抗の評価, 第 36 回地盤工学研究発表会, pp. 1579-1580, 2001.6

16）杉村義広ほか:低コストを目的とした大口径場所打ち杭の鉛直載荷試験, 基礎工, pp129-135，1997. 12

17）青木雅路, 平井芳雄ほか：場所打ち拡底杭の原位置引抜き試験結果（そ の 1 その 2), 第 36 回地盤工学研究発表会, pp. 1561-1564, 2001.6

18）海野隆哉, 青木一二三ほか : 短尺場所打ち杭の鉛直載荷試験, 第 18 回土 質工学研究発表会, pp. 989-992, 1983.6

19）筒井通剛, 高垣太平ほか: 場所打ち拡底杭の引抜き抵抗に関する研究 (そ の 1〜その 3)，第 29 回地盤工学研究発表会, pp. 1543-1548，1994. 6

20）渋谷孝男，小椋仁志ほか：関東郵政局等庁舎新築工事における大口径場 所打ち杭の先端載荷試験 (その 1 その 2), 第 32 回地盤工学研究発表会, pp. 1431-1434, 1997.7

21）小椋仁志ほか：太田市新庁舎建設工事における場所打ち杭杭先端載荷試 験, 日本建築学会大会学術講演梗概集, B-1 分冊, pp. 929-930, 1995.8

22）青木一二三ほか：高品質アースドリル杭の開発実験（その 1〜その 3), 第 33 回地盤工学研究発表会, pp. 1381-1386, 1998.7

23）久保裕一, 坪田邦治：伊勢湾と濃尾平野地域の圧密特性について, 中部 地質調査業協会 土と岩, pp. 42-44, 2008.4

24）日本建築学会 : 建築基礎構造設計指針, pp. 203-216, 2001

25）日本建築学会: 杭の鉛直支持力小委員会報告書 第 2 章先端支持力, pp. $58-61,2008.8$

（2013年 3 月 8 日原稿受理， 2013年 6 月 24 日採用決定） 